\title{
For the Most Part
}

National Cancer Institute

\section{Source}

National Cancer Institute. For the Most Part. NCI Thesaurus. Code C121916.

An indication that something has been mostly accomplished or has been mostly satisfying. 